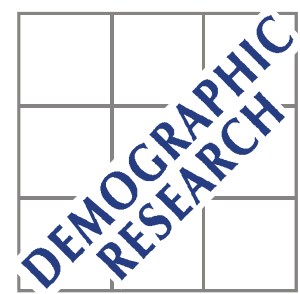

Demographic Research a free, expedited, online journal of peer-reviewed research and commentary in the population sciences published by the Max Planck Institute for Demographic Research Doberaner Strasse 114 · D-18057 Rostock · GERMANY www.demographic-research.org

DEMOGRAPHIC RESEARCH

VOLUME 3, ARTICLE 1

PUBLISHED 12 JULY 2000

www.demographic-research.org/Volumes/Vol3/1/

DOI: 10.4054/DemRes.2000.3.1

\title{
Old-Age Mortality in Germany prior to and after Reunification
}

Arjan Gjonça

Hilke Brockmann

Heiner Maier

(C) 2000 Max-Planck-Gesellschaft. 


\title{
Old-Age Mortality in Germany prior to and after Reunification
}

\author{
Arjan Gjonça ${ }^{1}$
}

Hilke Brockmann ${ }^{2}$

Heiner Maier $^{3}$

\begin{abstract}
Recent trends in German life expectancy show a considerable increase. Most of this increase has resulted from decreasing mortality at older ages. Patterns of oldest old mortality (ages 80+) differed significantly between men and women as well as between East and West Germany. While West German oldest old mortality decreased since the mid 1970s, comparable decreases in East Germany did not become evident until the late 1980s. Yet, the East German mortality decline accelerated after German reunification in 1990, particularly among East German females, attesting to the plasticity of human life expectancy and the importance of late life events. Medical care, individual economic resources and life-style factors are discussed as potential determinants of the decline in old age mortality in Germany.
\end{abstract}

\footnotetext{
${ }^{1}$ Department of Social Policy, London School of Economics, Houghton Street, London WC2A 2AE,UK; Phone: +44-171-955-7663; Fax: +44-171-955-6833; Email: A.Gjonca1@1se.ac.uk

${ }^{2}$ Max Planck Institute for Demographic Research, Doberaner Str. 114, D-18057 Rostock, Germany Phone: +49-381-2081-161; Fax: +49-381-2081-461; Email: brockmann@ demogr.mpg.de

${ }^{3}$ Max Planck Institute for Demographic Research, Doberaner Str. 114, D-18057 Rostock, Germany Phone: +49-381-2081-152; Fax: +49-381-2081-452; Email: maier@ demogr.mpg.de
} 


\section{Introduction}

Mortality patterns in Germany are an intriguing subject for social scientists. The recent German history offers a unique opportunity to study the effects of political, economic and social factors on mortality changes. Prior to 1945 East and West Germans shared a cultural and historical background that included the political system. Between 1949 and 1989, however, East and West Germans lived under different political and economic systems, a socialist planned economy (East Germany) versus a free-market democracy (West Germany). With German reunification in 1990 the two German populations were again integrated into one political and economic system.

The purpose of this study is to examine recent trends in old age mortality in Germany. We consider the period from 1970 to 1996, and we present mortality indicators separately for the former German Democratic Republic (East Germany) and the former Federal Republic of Germany (West Germany). The paper addresses two issues. First, we examine whether and to what degree increases in life expectancy were determined by increased survival at older ages. Secondly, we provide a detailed description of recent trends in mortality among the oldest old (ages 80+). In this context it is of interest to determine whether the changes associated with German reunification in 1990 altered any of the long-term trajectories of oldest old mortality.

Previous research indicated that life expectancy was somewhat different in East and West Germany. Immediately after the war, mortality was higher in East Germany than in West Germany [Scholz 1996]. However, this pattern changed quickly. By the early 1950s, mortality in East Germany had reached the pre-war level and, subsequently, even fell somewhat below West German figures. With regard to the male population, a slight East German lead lasted until the mid 1970s. Mortality for women was about the same in both German states from the early 1950s until the early 1970 s.

As of about 1970 mortality trends in East and West Germany diverged (see Figure 1). Life expectancy at birth in East Germany increased with a low gradient for both sexes, while life expectancy in West Germany rose more rapidly. With the collapse of the socialist regime in 1989 and German reunification one year later, life expectancy in East Germany began to increase at an accelerated pace. The increase in life expectancy was more pronounced for females than for males. However, this general trend towards increased life expectancy was accompanied by a temporary set-back for men. Detailed analyses indicated that male life expectancy actually declined in East Germany immediately before and after reunification. For males, the 1989 level was not reached again until 1992. This short peak in mortality was due to higher death rates in men aged 15 to 65 [Häussler, Hempel, and Reschke 1995, Dorbritz and Gärtner 1995]. Older age groups did not experience a similar increase in death rates. Mortality for these older age 
groups continued to decrease gradually [Häussler, Hempel, and Reschke 1995, Schott, Bergmann, and Wiesner 1995].

Demographers have documented the remarkable increases in survival at older ages in developed countries. During the $20^{\text {th }}$ century death rates at older ages have fallen dramatically in many European countries [Kannisto et al. 1994, Vaupel 1997]. Mortality decreases have been more pronounced for females than males, and the pace of decline has been more rapid in recent decades than it was in earlier decades. One goal of the present study was to explore whether similar trends can also be observed for the two German states.

In sum, the present study focuses on trends in old age mortality in Germany. In a first step we examine the contribution of different age groups to changes in life expectancy, separately for the two German states and for different time periods (prior to, during, and after reunification). Our goal was to evaluate whether and to what degree increases in life expectancy were determined by increased survival at older ages. In a second step we investigate changes in oldest old mortality (ages 80+) for the period between 1955 and 1996, again separately for the two German states. Utilizing Lexis maps [Andreev 1999, Vaupel et al. 1998] we present death rates for each age (80 to 99 ) and each year (1955 to 1996). Our goal was to obtain a detailed description of trends in old age mortality in Germany in recent decades, and to assess whether these trends were altered by German reunification. In the final section we discuss potential determinants of old age mortality in Germany, with an emphasis on medical and nursing care, individual economic resources, and life-style factors. 


\section{Data and methods}

The empirical analyses in this paper are based on two different sets of data. Data published by the German Statistical Office [Statistisches Bundesamt 1980-1998] are used to examine mortality patterns across all ages and to investigate the contribution of different age groups to changes in life expectancy. The second data set used in this study is the Kannisto-Thatcher Oldest Old Database [Kannisto 1994], a database that was specifically designed to investigate mortality at the ages of 80 and above.

A decomposition method [Pollard 1988, p266, equation 3] is used to analyze the contribution of different age groups to changes in life expectancy at birth. Results obtained with this method are reasonably accurate as long as the increases in life expectancy are modest, as is the case with East and West Germany. The decomposition method is applied for the whole period under consideration, 1980-1996, as well as broken down into three parts: 1980-1987 (prior to reunification), 1987-1992 (the period of reunification), and 1992-1996 (the period after reunification). The results obtained from the analyses of contribution of different ages to changes of life expectancy at birth are shown in Figures $2 \mathrm{a}$ (females, East Germany), $2 \mathrm{~b}$ (females, West Germany), 3a (males, East Germany), and 3b (males, West Germany).

The decomposition of change in life expectancy at birth is based on absolute changes in age-specific death rates, and absolute changes tend to be greater at older ages, where death rates are high. In addition to the decomposition analysis, we present average annual rates of mortality decline [e.g. Wilmoth and Horiuchi 1999, p486] by age and sex in order to investigate relative mortality decline. The rates of relative change in mortality are shown in Figures 4a (females, East Germany), 4b (females, West Germany), 5a (males, East Germany), and 5b (males, West Germany).

When it comes to mortality at the oldest ages, the Kannisto-Thatcher Oldest Old Database is presumably a better source of information than mortality estimates published by the German Statistical Office, because it relies on the method of extinct generations. This method [Vincent 1951] builds up the history of a cohort (its size by age and sex) by summing up data on deaths beginning with the oldest individual for a cohort which has died out. The cohort history was chosen because central death rates are most accurately calculated when a closed group of persons is followed up from one exact age to the next. It is known that accuracy becomes increasingly important when the numbers are small, as is the case at the oldest ages.

Specifically, the Kannisto-Thatcher Oldest Old Database includes data on deaths by sex and by single year of age combined with the year of birth. The data begin at age 80 and start with the year 1950 for most of the 31 countries that are presently included in the database. There is no upper limit for age for most of the countries. For some countries, however, the age limit is 99 years. Kannisto [Kannisto 1994] studied the quality and reliability of German mortality data and 
concluded that the data on deaths were accurate for both East and West Germany. Information on cause of death is not included in the database. Cause-of-death data (particularly for old decedents) have many problems. Comparative analyses involving cause-of-death data for the period prior to German unification are even more problematic because the two German states used rather different coding procedures [Brückner 1993, Dinkel 1999].

In the present study we developed Lexis maps based on these data for ages 80 and over and for the period 1950-1996 (see Figures 6 and 7). Lexis maps can be used to graphically display mortality changes over time and separately for different ages. The maps presented here are based on mortality indicators whose layers differ by color. The colors indicate different death rates in Figure 6 and different death rate ratios in Figure 7. 


\section{Results}

\subsection{Changes in mortality across all ages}

During the period 1980-1996 life expectancy increased by 5.3 years for females and 3.1 years for males in East Germany, compared to 3.4 years for West German females and 3.9 years for males. Thus, the increase in life expectancy was most pronounced among East German females. When the period 1980 to 1996 is broken down into the three periods 1980-1987, 19871992, and 1992-1996, then it becomes obvious that the mortality changes were not synchronized for both sexes in the two former states. Most of the mortality decline for East German females occurred during the period 1992-1996 (see Figures 2a and 4a), while for West German females the period 1980-1987 was more important (see Figures $2 b$ and $4 b$ ). The same is true for changes in male mortality. The period 1992-1996 was most important for the mortality decline among East German males (see Figures 3a and 5a), while the period 1980-1987 was most important for the mortality decline among their West German counterparts (see Figures $3 b$ and 5b).

There are several interesting patterns with respect to mortality in early and middle adulthood. For both sexes and in both German states, the period around unification (1987-1992) was least efficient in reducing mortality in these adult ages. For example, for East German females aged 30-49 years, mortality actually increased during this period (see Figures $2 \mathrm{a}$ and $4 \mathrm{a}$ ). This upward trend in mortality in the period around unification was even more emphasized among East German males, where mortality increased for all ages from 15 to 64 (see Figures 3a and 5a). Another distinctive pattern is that the period prior to unification (1980-1987) was most efficient in reducing West German female (Figures $2 b$ and $4 b$ ) and male (Figures $3 b$ and $5 b$ ) adult mortality when compared to the other two periods. This is in contrast to the pattern observed in East Germany, where the period after unification (1992-1996) was most efficient in reducing adult mortality for both females (Figures $2 \mathrm{a}$ and $4 \mathrm{a}$ ) and males (Figures $3 \mathrm{a}$ and 5a).

An interesting picture emerged for a cohort of East and West German men who were born in the late-1920s and who were aged about 65-69 years in 1992-1996. Their mortality decline was less pronounced when compared to the adjacent cohorts (see Figures 3 and 5). These men were adolescents during the Second World War, and they may have acquired additional risks through the hardships of the war. Note that Horiuchi [Horiuchi 1983] documented elevated mortality at older ages among male cohorts in Germany who were adolescents during the First World War.

Infant and child mortality continued to decline gradually from 1980 to 1996 . This was the case for both German states and for males and females (see Figures 2-5). It seems that German reunification did not alter trends in infant and child mortality. 


\subsection{The contribution of older age groups ( 60 and over)}

The older age groups contributed most to the increase in life expectancy at birth for females in East (Figure 2a) and West (Figure 2b). This is reflected in the period 1980-1996 as a whole, as well as when it is broken down into the periods 1980-87, 1987-92, and 1992-96. Life expectancy at birth for females in East Germany increased by 5.3 years. More than $71 \%$ of this increase came from ages 60 and above, and about $31 \%$ from ages 80 and above (see Figure 2a). Life expectancy at birth for females in West Germany increased by 3.4 years. Ages over 60 contributed $61 \%$ to this increase and ages over 80 contributed $22 \%$ (see Figure $2 \mathrm{~b}$ ). Thus, the contribution from the old ages to the increase in female life expectancy was quite substantial, particularly in East Germany.

The period after reunification (1992-1996) was characterized by a substantial reduction in female old age mortality in East Germany (Figures 2a and 4a), while the period 1980-1987 was the most important for the reduction among females in West Germany (Figures $2 b$ and $4 b$ ). This is similar to the patterns observed in early and middle adulthood. In contrast to the patterns observed among younger women, reunification did not coincide with an increase in old age mortality. Quite the reverse was true: old age mortality decreased. Note that Figures 2a and 4a also suggest that female mortality in East Germany, in particular at old ages, started declining prior to reunification. However, it was during 1987-1992 and 1992-1996 that the pace of the mortality decline accelerated.

The pattern for males (Figures $3 \mathrm{a}$ and $3 \mathrm{~b}$ ) was somewhat different from that of females. The contribution of old and oldest ages was less prominent for males than for females in both East and West Germany. During 1980-1996 male life expectancy at birth increased by 3.1 years in East Germany. $62 \%$ of this increase came from ages 60 and over, and 17\% from ages 80 and over. In West Germany male life expectancy increased by 3.9 years from 1980 to 1996 . Ages over 60 contributed $60 \%$ and ages over 80 contributed $9 \%$. Although the pace of mortality decline at the oldest old ages was slower for males than for females, it is obvious that there was also a considerable decline in old age mortality among men in both East and West Germany.

To summarize, Figures $2 a, 2 b, 3 a$, and $3 b$ indicate that most of the increases in life expectancy came as a result of decreasing mortality at older ages (ages over 60). This pattern was observed for males and for females, in East Germany as well as in West Germany. The pattern was more pronounced for females than for males, and it was more obvious in East than in West Germany. 


\subsection{Changes in oldest old mortality ( 80 and over)}

A fair amount of the mortality decline in both East and West Germany can be attributed to the oldest old (ages 80+). A detailed observation of mortality changes at these ages is shown in Figure 6, where central death rates are plotted, separately for East and West Germany as well as for males and females. The period covered is 1955-1996.

An examination of these historical trends indicates that oldest old mortality decline in East Germany was present as of the late 1980s. The decline accelerated in the 1990s, particularly among females. A closer look at the female map for East Germany suggests that around reunification there was an acceleration of the mortality decline for almost all oldest old ages (80+). This explains the high contribution of ages over 80 to changes of life expectancy at birth during 1987-92, as shown in Figure 2a.

A different picture is portrayed in West Germany. Female mortality at the oldest ages started to decrease in the early 1970s. Here the mortality decline was gradual and it affected all ages 80 and over. For males the mortality decline started later, around 1980. Similar to females, the decline was gradual during the remaining period. A distinctive feature for females in both East and West Germany is that we see a mortality decline even at the very old ages over 95.

Figure 7 shows the ratios of the central death rates in East and West Germany for both males and females. The color red indicates lower death rates in East Germany; the color blue signifies lower death rates in West Germany. The scale on the right shows the ratio of East/West German central death rates. For example, a ratio of 1.1 indicates that mortality in East Germany is $10 \%$ higher than in West Germany.

The Lexis maps for both sexes indicate that East and West Germany had similar levels of oldest old mortality (ratios close to 1.0) until about 1970. The female advantage of West Germany started in the 1970s, while the male advantage started in the 1980s. For females the gap diverged further in the 1980s. Female oldest old mortality in East Germany was sometimes $30 \%$ higher than in West Germany. The male map shows that the divergence in the 1980s was not as pronounced as it was for females. Male mortality among the oldest old in East Germany was sometimes $20 \%$ higher than in West Germany.

There appears to be a time lag of about five to ten years between female and male changes, with mortality changes for females preceding changes for males. This lag was observed in West Germany when female mortality started declining in the 1970s while male mortality followed this decline in the 1980s (see Figures 6 and 7). Similarly, in East Germany the rapid decline of female mortality at the end of the 1980s and in the early 1990s is now being experienced by males in the last years of 1990s (see Figure 6).

For both sexes the East-West German gap was wider in the late 1980s and it seems to be closing in the 1990s. Interestingly, the disappearance of the large West German advantage is most salient for the very old ages (ages over 90). It is even more emphasized among 
centenarians. Table 1 lists the absolute number and the proportion of centenarians (ages 100 and over) in 1990 and 1996, separately for East and West Germany as well as for women and men. During this period there was a rapid increase in the number of centenarians in both parts of Germany. However, the increase was more pronounced in East Germany. During 1990-1996 the number of female centenarians in East Germany increased by a factor of 2.51 (184 centenarians in 1990 versus 461 centenarians in 1996). The number of female centenarians in West Germany in that same period increased only by a factor of 1.88. Similarly, the increase in the number of male centenarians was more pronounced in East Germany (factor 1.49) than it was in the West (factor 1.13). 


\section{Discussion}

It is tempting to attribute the apparent closing of the oldest old mortality gap between East and West Germany to the historical drama of political reunification. Putting an obvious cause to an obvious trend has a certain prima facie plausibility. However, the old-age patterns we have presented suggest that some of the mortality decline in East Germany actually started prior to reunification. We also observed considerable similarities between the two German states that were only gradually affected by reunification. For example, it appears that the increase in life expectancy after 1980 was dominated by the prolongation of life at older ages in both German states. Another similarity between East and West Germany was that the decline in old age mortality was greater among women than men.

This is not to say that reunification did not have any impact, or that differences between East and West Germany were negligible. One profound difference between the two German states was that decline in old age mortality prior to reunification was much more pronounced in West than in East Germany. Mortality at ages 80 and above started to decline in West Germany in the mid 1970s. Not until ten years later did oldest old mortality begin to decrease in East Germany. And it occurred at a slower pace. German reunification in 1990 had little, if any effect on the long-term trend of oldest old mortality in West Germany. In contrast, East German death rates at the oldest ages decreased markedly after 1990. It appears that this downward trend after reunification was not only a continuation of a trend started earlier, but that it reflects an accelerated pace of decline in old age mortality in East Germany.

How can we explain the late-life mortality patterns observed in the two German states? A growing body of research documents that early-life and mid-life conditions are important determinants of late-life mortality. Some researchers focused on the effects of mid-life events and exposure to health risk on late-life mortality [e.g. Manton, Stallard, and Corder 1997]. Others investigated the effects of malnutrition, infectious diseases and other types of biomedical and socioeconomic stressors early in life on adult health and mortality [e.g. Barker 1992, Davey Smith et al. 1998, Elo and Preston 1992, Fogel and Costa 1997]. However, there is also conflicting evidence that suggests that current conditions may be much more important than conditions earlier in life [Christensen et al. 1995, Kannisto, Christensen, and Vaupel 1997]. Kannisto [Kannisto 1994] studied the development of oldest old mortality in several developed countries, and Dinkel [Dinkel 1992] analyzed mortality trends in German cohorts. Both concluded that period factors with immediate effects were considerably more significant than cohort effects. Consistent with this conclusion, results from our study provide little evidence for the presence of cohort effects. Our central findings were that old-age mortality declined earlier and gradually in West Germany, and that East Germany was characterized by later and more abrupt decline that coincided with German reunification. These developments occurred 
simultaneously in all age groups studied (see Figures 6), and there was no evidence for a time lag which could be indicative of a cohort effect.

Of particular interest are the mortality trajectories of East German individuals who experienced the transition from a socialist planned economy to a free-market democracy late in their lives. Here we observed this rather sudden mortality decline that suggests a period effect. Moreover, it appears that this period factor operated without delay because the mortality decline became visible immediately after reunification. This is somewhat surprising, because traditional epidemiological risk factors such as nutrition or changes in the health care system are thought to operate over rather long time periods [Manton, Stallard, and Corder 1997]. However, there are also intervention studies suggesting that dietary changes can have immediate and profound effects on health [e.g. Stich et al. 1991]. It is also true that some of the changes that came with reunification came indeed rather quickly. The social and economic union between the two German states was established in July 1990, and pensions were paid in Western currency and raised to West German levels after that date [Frerich and Frey 1990]. Similarly, laws implementing the Western medical care system in East Germany were passed in the summer of 1990, and East Germans were eligible to receive health care according to Western standards after that date. Thus, it was possible to transfer patients to Western facilities if a particular treatment was not available in the East.

For these reasons, we restrict our discussion to migration as a selection factor and to three factors with presumably causal effects: medical and nursing care expenditures, economic resources, and life-style factors. The health care and pension systems were part of the institutional transfer of reunification and were altered overnight. Life-style factors were only indirectly affected by the historical event of unification, and changes in behavioral and life-style factors occurred probably less abrupt.

\subsection{Migration}

Some scholars [Häussler, Hempel, and Reschke 1995, Dinkel 1999] highlight a so-called "positive migration effect." They argue that between 1945 and 1961, when the Berlin Wall was built, many young adults and their families left East Germany and moved to West Germany while the elderly and unfit stayed. There is considerable empirical support for a healthy migration hypothesis in general [Fox, Goldblatt, and Adelstein 1982]. However, to our knowledge there is no empirical evidence that migration of the young and healthy in fact contributed to the difference in old-age mortality between East and West Germany.

In contrast, Schott et al. [Schott et al. 1994] focus on a so-called "negative migration effect." They argue that after the war millions of refugees fled from the Soviet army and most of them eventually settled down in West Germany. The hardship they met on their way to West 
Germany may have weakened their physical constitution, which in the long run may have contributed to higher mortality rates in West Germany. We are not aware that this hypothesis has been tested empirically. Both the positive and the negative migration hypothesis seem plausible, but no firm conclusions can be drawn in the absence of empirical support for either hypothesis. It is also possible that both hypotheses are true but that their effects cancel out.

\subsection{Medical and nursing care}

An analysis of the differences in the welfare regimes of East and West Germany may help to explain the observed mortality patterns. This is particularly true for the oldest age groups, which strongly depend on welfare transfers. In general, the welfare regime of the former German Democratic Republic can be characterized as "means tested" and "service heavy." That is, the welfare regime was targeted at fulfilling the basic needs of individuals and it operated primarily through the provision of services. In addition, this welfare system focused on the young and middle-aged population.

In contrast, the West German welfare regime can be characterized as "status preserving" and "transfer heavy." That is, the West German welfare system focused on preserving the status of individuals when they were confronted with hardships, and it operated primarily through monetary payments. It has been argued that the status preserving and transfer heavy West German system disproportionately favored the elderly [Hockerts 1998, Lampert 1996, ManowBorgwardt 1994].

Transfer payments to the elderly - i.e., pension payments and health care expenditures were several times higher in West than in East Germany [Statistisches Bundesamt 1994, Verband Deutscher Rentenversicherungsträger 1999]. However, an exact comparison is difficult because both countries defined their statistics differently. Relative trends in social expenditures may give a better picture of the extent of services rendered to the elderly population. Between 1970 and 1989 expenses for medical care quadrupled in West Germany. But even in the former German Democratic Republic, where the economy eventually went bankrupt [Ritschl 1995], health care expenditures more than tripled during the same period. It is noteworthy that increases in medical expenditures rose steeper between 1986-1988 than before [Statistisches Bundesamt 1994]. As women make more use of medical services than men do, they might have benefited more from medical care improvements in East Germany before reunification.

Starting in 1970 the former German Democratic Republic tried to improve the supply of old age care [Ziesemer 1990, Bardehle and Voß 1990, Schönfeld 1990]. Although the number of places in nursing homes increased from 96,000 in 1970 to 140,000 in 1988 , it was still the case that more than 100,000 applicants could not be admitted to homes because of a lack of space. Further, the quality of care in those institutions remained relatively low. Regular medical check 
ups and rehabilitation were not possible [Schmidt 1990], and there was a chronic shortage of trained nurses.

Children who wanted to care for their frail parents were faced with several obstacles. Women were the major caregivers, and in East Germany nearly all women participated in the labor force. Giving up employment in order to care for an old parent implied that these women had to give up their social security benefits. There was also no market for social services or medical aid that could be relied upon, and appropriate apartments for frail elderly people were scarce.

With respect to old age mortality, it was probably crucial that the former German Democratic Republic did not keep pace with the international medical progress that took place in the field of chronic diseases. The fight against chronic diseases, from which many older persons suffer, is capital-intensive. Many scholars argue that the lack of economic dynamism is one of the main reasons why the health care regime of East Germany started to fall behind in the 1970s. The lack of domestic innovations and the lack of foreign currency to buy new innovations from the West led to a stratified, rationing health care system [Volpp 1991]. After reunification in 1990, the shortage of adequate medical equipment and treatment became obvious [Bause and Matauschek 1990, Sachverständigenrat für die Konzertierte Aktion im Gesundheitswesen 1991]. About $17 \%$ of hospitals were rundown to a greater or lesser extent, $30 \%$ of the beds used in clinics were beyond repair, and medical technology was trailing behind Western standards by 15 to 20 years [Mielck 1991]. It was estimated that 1.5 billion DM would be needed to update the medical technology [Becker 1990]. Further, the available amount of nearly 2,000 different drugs was not considered adequate, given the fact that 40,000 drugs were on the market in West Germany. Experts also estimated that the need for dialysis was only met in $38 \%$ of all cases, and the demand for kidney transplants and open-heart surgery was met in only $50 \%$ of all cases [Arnold and Schirmer 1990, Korbanka 1990, Thiele 1990].

Studies on mortality from conditions amenable to medical intervention confirm that medical resource deficiencies are decisive [Velkova, Wolleswinkel-Van den Bosch, and Mackenbach 1997]. It is well documented that a lack of appropriate medical care has immediate effects on mortality at older ages. We can speculate that the financial weakness of the socialist health care system in East Germany was one of the main reasons why the decline in old age mortality was relatively slow prior to reunification. After reunification the Western health care system was quickly installed in East Germany. Consequently, the accelerated decline in old age mortality described above occurred. 


\subsection{Economic resources}

Pension payments made up the largest share of social expenditures in both German states. Due to the different welfare regimes, however, both the absolute amount and the relative increase were much smaller in East than in West Germany prior to 1989. Comparing the average income of households, we see that in both German states pensioners have considerably less income than people in the work force. In 1985, a household with a retired head had 36\% in East Germany and $65 \%$ in West Germany of the income of a household with an employed head, respectively.

After reunification the West German pension scheme was transmitted to East Germany, which made retired people one of groups that benefited most from the transformation. In 1990 the monthly pension of an East German retired employee was 40\% that of his or her West German counterpart. This income gap diminished quickly in the following years. In 1999 an East German pensioner received on average $87 \%$ of what a West German pensioner got [Presseund Informationsamt der Bundesregierung 1999]. Particularly women from East Germany have benefited because they had, on average, considerably longer working biographies than their West German counterparts.

The shift from a relatively deprived to a relatively privileged living situation probably affected the health and mortality of the oldest old. There is an extended literature on socioeconomic differentials in mortality [Hummer, Rogers, and Eberstein 1998] that suggests that individual resource availability increases health chances and, ultimately, survival. It is quite likely that the increased individual resources and opportunities that came with reunification have also contributed to the accelerated decline in death rates in East Germany.

\subsection{Life-style factors}

The interaction between material resources, health, and longevity is probably mediated through various behavioral choices. Demographers and epidemiologists focus on eating and drinking habits, smoking behavior and exercise. Pre-unification comparisons between East and West German nutritional habits revealed a significantly lower consumption of milk, vegetable oil and fat, fresh vegetables and tropical fruits in East Germany, while the intake of sausages, baked goods, butter and spirits was significantly higher. The calorie intake in East Germany was also considerably higher for fat and lower for carbohydrates [Winkler, Holtz, and Döring 1992a, 1992b, Thiel and Heinemann 1996].

After 1989 consumption patterns changed. Individuals in East Germany consumed more carbohydrates, vitamins, calcium, and potassium. Consumption of fresh fruits increased while the intake of baked goods and meat decreased [Winkler, Brasche, and Heinrich 1997]. These consumption patterns may help to explain both why old age mortality patterns in East and West 
Germany diverged before reunification and why they then converged after reunification. One cannot, however, come to a conclusive interpretation here, since the nutritional studies cited above all involved individuals at younger ages.

There is evidence to suggest that older people rarely change their eating habits [Brockmann 1998]. Rather than improving their diet, they tend to avoid food that is difficult to chew, such as fresh fruit and vegetables. On the other hand, many people above the age of 80 do not cook for themselves. Some live in institutions, others make use of food delivery services. In this way, elderly people in East Germany might well have profited from a better food supply after reunification without actually changing their individual behavior.

\subsection{Conclusion}

During the past two decades there has been a substantial decline in old age mortality in both German states. The decline was more pronounced for women than for men. The decline in West Germany seems to follow a gradual, long-term trend. The decline in East Germany was accelerated after reunification, and it appears that the East-West German gap in old age mortality is closing. This effect of German reunification on old age mortality in East Germany attests to the plasticity of human life expectancy at older ages and to the importance of late-life events.

Many Germans are ambivalent about the balance of gains and losses that came with reunification [Schmitt, Maes, and Seiler 1999] and wonder what reunification will ultimately bring. Old age mortality is just one of many aspects of human development that might be used to evaluate the effects of reunification, and this aspect seems to suggest that reunification did have a beneficial effect: death rates of the oldest old in East Germany fell considerably after reunification. The specific mediating factors for this effect remain unknown, but it is likely that improvements in the health care system played a major role. It is also likely that there was not only one mediating factor. Rather, we believe that reunification and the many changes that came with it affected old age mortality through various pathways including individual economic resources and life-style factors. 


\section{Acknowledgements}

The research presented here was sponsored by and carried out at the Max Planck Institute for Demographic Research (MPIDR) in Rostock, Germany. We thank Kirill Andreev, Karl Brehmer, Reiner H. Dinkel, Silvia Leek, James W. Vaupel, and three anonymous reviewers.

Correspondence concerning this article should be addressed to Arjan Gjonça, Department of Social Policy, London School of Economics and Political Science, Houghton Street, London WC2A 2AE, UK. Electronic mail may be sent via the Internet to A.Gjonca1@1se.ac.uk. 


\section{References}

Andreev, K. (1999). Demographic surfaces: "Estimation, assessment, and presentation with application to Danish mortality, 1835-1995". Unpublished doctoral dissertation, University of Southern Denmark.

Arnold, M., and B. Schirmer. (1990). "Gesundheit für ein Deutschland". Köln, Germany: Deutscher Ärzte-Verlag.

Bardehle, D., and G. Voß. (1990). "Finanzielle Aufwendungen für Feierabend- und Pflegeheime", pp. 71-75, in: D. Bardehle (ed.), Übersichten zur Betreuungssituation älterer Bürger in der DDR. Berlin, Germany: Deutsches Zentrum für Altersfragen.

Barker, D.J.P. (1992). "Fetal and infant origins of adult disease". London: British Medical Journal.

Bause, U., and J. Matauschek. (1990). "Zum Stand der Medizintechnik in der DDR", pp. 197206, in: W. Thiele (ed.), Das Gesundheitswesen der DDR: Aufbruch oder Einbruch? Sankt Augustin, Germany: Asgard-Verlag.

Becker, J. (1990). "526 Großgeräte sind nötig zur Niveau-Angleichung", Ärzte Zeitung, 234: 12.

Brockmann, H. (1998). "Die Lebensorganisation älterer Menschen". Wiesbaden, Germany: Deutscher Universitätsverlag.

Brückner, G. (1993). "Todesursachen 1990/91 im vereinten Deutschland", Wirtschaft und Statistik, 4: 257-278.

Christensen, K., J.W. Vaupel, H.V. Holm, and A.I. Yashin. (1995). "Mortality among twins after age 6: fetal origins hypothesis versus twin method", British Medical Journal 310: 432-436.

Davey Smith, G.D., C. Hart, D. Blane, and D. Hole. (1998). "Adverse socioeconomic conditions in childhood and cause specific adult mortality: prospective observational study", British Medical Journal 316: 1631-1635.

Dinkel, R.H. (1992). "Kohortensterbetafeln für Geburtsjahrgäng ab 1900 bis 1962 in den beiden Teilen Deutschlands", Zeitschrift für Bevölkerungswissenschaft 18(1): 95-116.

Dinkel, R.H. (1999). "East and West German mortality before and after reunification". Unpublished manuscript, University of Rostock.

Dorbritz, J., and K. Gärtner. (1995). "Bericht 1995 über die demographische Lage in Deutschland", Zeitschrift für Bevölkerungswissenschaft 20: 339-448.

Elo, I.T., and S.H. Preston. (1992). "Effects of early-life conditions on adult mortality: a review", Population Index 58(2): 186-212.

Fogel, R.W., and D.L. Costa. (1997). "A theory of technophysio evolution, with some implications for forecasting population, health care costs, and pension costs", Demography 34(1): 49-66. 
Fox, A. J., P.O. Goldblatt, and A.M. Adelstein (1982). "Selection and mortality differentials", Journal of Epidemiology \& Community Health 36: 69-79.

Frerich, J., and M. Frey. (1996). "Handbuch der Geschichte der Sozialpolitik in Deutschland", Band 3. München, Germany: Oldenbourg Verlag.

Häussler, B., E. Hempel, and P. Reschke (1995). "Die Entwicklung der Lebenserwartung und Sterblichkeit in Ostdeutschland nach der Wende (1989-1992)", Das Gesundheitswesen 57: 365-372.

Hockerts, H. G. (1998). "Einführung", pp. 7-25, in: H. G. Hockerts (ed.), Drei Wege deutscher Sozialstaatlichkeit. NS-Diktatur, Bundesrepublik und DDR im Vergleich. München, Germany: R. Oldenbourg Verlag.

Horiuchi, S. (1983). "The long-term impact of war on mortality: old-age mortality of the first world war survivors in the Federal Republic of Germany", Population Bulletin of the United Nations 15: 80-92.

Hummer, R., R. Rogers, and I. Eberstein (1998). "Sociodemographic differentials in adult mortality: A review of analytic approaches", Population and Development Review, 24(3): 553-578.

Kannisto, V. (1994). "Development of oldest-old mortality 1950-1990". Odense, Denmark: Odense University Press. Electronic edition: http://www.demogr.mpg.de/Papers/Books/Monograph1/OldestOld.htm.

Kannisto, V., K. Christensen, and J.W. Vaupel (1997). "No increased mortality in later life for cohorts born during famine", American Journal of Epidemiology, 145(11): 987-994.

Kannisto, V., J. Lauritsen, A.R. Thatcher, and J.W. Vaupel 1994. "Reductions in mortality at advances ages: Several decades of evidence from 27 countries", Population and Development Review, 20(4): 793-810.

Korbanka, C. (1990). "Das Gesundheitswesen der DDR. Darstellung und Effizienzanalyse". Köln, Germany: Müller Botermann Verlag.

Lampert, H. (1996). "Lehrbuch der Sozialpolitik" (4 ${ }^{\text {th }}$ ed.). Berlin, Germany: Springer.

Manow-Borgwardt, P. (1994). "Die Sozialversicherung in der DDR und der BRD, 1945-1990: Über die Fortschrittlichkeit rückschrittlicher Institutionen", Politische Vierteljahresschrift 35(1): 40-61.

Manton, K.G., E. Stallard, and L. Corder. (1997). "Changes in the age dependence of mortality and disability: cohort and other determinants", Demography, 34(1): 135-157.

Mielck, A. (1991). "Mortalität und Lebenserwartung: Unterschiede zwischen Ost- und Westdeutschland", Sozialer Fortschritt 9: 220-223.

Pollard, J. H. (1988). "On the Decomposition of changes in expectation of life and differentials in life expectancy", Demography, 25(2): 265-276. 
Presse- und Informationsamt der Bundesregierung. (1999). "Einkommensfortschritt der Rentner", Sozialpolitische Umschau 158: 1.

Ritschl, A. (1995). "Aufstieg und Niedergang der Wirtschaft der DDR: Ein Zahlenbild 19451989", pp. 11-46, in: H. v. Lehmann (ed.), Jahrbuch für Wirtschaftsgeschichte 1995/2. Berlin, Germany: Akademie Verlag.

Sachverständigenrat für die Konzertierte Aktion im Gesundheitswesen. (1991). Jahresgutachten 1991. "Das Gesundheitswesen im vereinten Deutschland. Baden-Baden", Germany: Nomos Verlag.

Schmidt, B. (1990). "Ältere und geschädigte Bürger", pp. 115-120, in: W. Thiele (ed.), Das Gesundheitswesen der DDR: Aufbruch oder Einbruch? Sankt Augustin, Germany: AsgardVerlag.

Schmitt, M., J. Maes, and U. Seiler. (1999). "Soziale Identität als Gradmesser der menschlichen Annäherung im wiedervereinigten Deutschland", pp. 160-174, in: H. Berth and E. Brähler (eds.), Deutsch-deutsche Vergleiche: psychologische Untersuchungen 10 Jahre nach dem Mauerfall. Berlin, Germany: Verlag für Wissenschaft und Forschung.

Scholz, R. (1996). "Analyse und Prognose der Mortalitätsentwicklung in den alten und neuen Bundesländern - Ergebnisse des Ost/West-Vergleiches der Kohortensterblichkeit", pp. 89102, in: R. Dinkel, C. Höhn, and R. Scholz (eds), Sterblichkeitsentwicklung - unter besonderer Berücksichtigung des Kohortenansatzes. München, Germany: R. Oldenbourg Verlag.

Schönfeld, G. (1990). "Kapazitätsentwicklung und Bausubstanzanalyse von Feierabend- und Pflegeheimen in der DDR", pp. 77-88, in: D. Bardehle (ed.), Übersichten zur Betreuungssituation älterer Bürger in der DDR. Berlin, Germany: Deutsches Zentrum für Altersfragen.

Schott, J., K. Bergmann, and G. Wiesner (1995). "Der Lebensverlängerungsprozeß - ein Vergleich zwischen Ost- und Westdeutschland", Zeitschrift für Bevölkerungswissenschaft 20(2): 187-206.

Schott, J., G. Wiesner, W. Casper, and K. Bergmann (1994). "Entwicklung der Mortalität des alten Menschen in Ost- und Westdeutschland in den zurückliegenden Jahrzehnten", pp. 171-182, in: A. Imhof and R. Weinknecht (eds.), Erfüllt leben - in Gelassenheit sterben. Geschichte und Gegenwart. Berlin, Germany: Duncker \& Humblot.

Statistisches Bundesamt (1980-1998). Statistische Jahrbücher 1980-1998. Wiesbaden, Germany: Statistisches Bundesamt.

Statistisches Bundesamt (1994). "Einnahmen und Ausgaben des Staatshaushalts 1970 bis 1989". Sonderreihe mit Beiträgen für das Gebiet der ehemaligen DDR, Vol. 12. Wiesbaden, Germany: Statistisches Bundesamt. 
Stich, H.F., B. Mathew, R. Sankaranarayanan, and M.K. Nair (1991). "Remission of precancerous lesions in the oral cavity of tobacco chewers and maintenance of the protective effect of beta-carotene or vitamin A", American Journal of Clinical Nutrition, 53: S298-S304.

Thiel, C. and L. Heinemann (1996). "Nutritional behaviour differences in Germany", Reviews of Environmental Health 11: 35-40.

Thiele, W. (1990). "Das Gesundheitswesen der DDR: Aufbruch oder Einbruch?" Sankt Augustin, Germany: Asgard-Verlag.

Vaupel, J.W. (1997). "The remarkable improvements in survival at older ages", Philosophical Transactions of the Royal Society of London - Series B: Biological Sciences 352(1363): 1799-1804.

Vaupel, J.W., W. Zhenglian, K.F. Andreev, and A.I Yashin. (1998). "Population data at a glance: Shaded contour maps of demographic surfaces over age and time". Odense, Denmark: Odense University Press. Electronic edition:

http://www.demogr.mpg.de/Papers/Books/Monograph4/PopData1.htm

Velkova, A., J. Wolleswinkel-Van den Bosch, and J. Mackenbach. (1997). "The East-West Life Expectancy Gap: Differences in mortality from conditions amenable to medical intervention", International Journal of Epidemiology 26: 75-84.

Verband Deutscher Rentenversicherungsträger (1999). "Die Deutsche Rentenversicherung 1998 - Jahresbericht des VDR". Frankfurt/Main, Germany: Verband Deutscher Rentenversicherungsträger.

Vincent, P. (1951). "La mortalite des veillards", Population 6(2): 181-204.

Volpp, K. (1991). "The structure of health care delivery in communist East Germany", Medizin, Mensch, Gesellschaft (MMG) 16: 3-13.

Wilmoth, J. R. and Horiuchi, S. (1999). "Rectangularization revisited: variability of age at death within human populations", Demography, 36(4): 475-497.

Winkler, G., S. Brasche, and J. Heinrich (1997). "Ernährungserhebung bei Erwachsenen in Erfurt 1991/92", Zeitschrift Für Ernährungswissenschaft 36: 143-150.

Winkler, G., H. Holtz, and A. Döring (1992a). "Comparision of food intakes of selected populations in former East and West Germany: results from the MONICA projects Erfurt and Augsburg", Annals of Nutrition \& Metabolism 36: 219-234.

Winkler, G., H. Holtz, and A. Döring (1992b). "Zum Verzehr ausgewählter Lebensmittel in Ostund Westdeutschland", Ernährungs-Umschau 39(5): 200-202.

Ziesemer, H. (1990). "Zur Statistik über die Betreuung älterer und pflegebedürftiger Bürger in Feierabend- und Pflegeheimen der ehemaligen DDR", pp. 45-69, in: D. Bardehle (ed.), Übersichten zur Betreuungssituation älterer Bürger in der DDR. Berlin, Germany: Deutsches Zentrum für Altersfragen. 


\section{Table 1:}

Number and Proportion of Centenarians (Persons Aged 100 and Above) in East and West Germany: 1990 and 1996

\begin{tabular}{|c|c|c|c|c|c|c|}
\hline & \multicolumn{3}{|c|}{ Number of Centenarians } & \multicolumn{3}{|c|}{$\begin{array}{l}\text { Proportion of Centenarians per } \\
\text { Million Population }\end{array}$} \\
\hline & Male & Female & Total & Male & Female & Total \\
\hline East 1990 & 47 & 184 & 231 & 6.1 & 21.9 & 14.3 \\
\hline East 1996 & 70 & 461 & 531 & 9.3 & 58.1 & 34.4 \\
\hline West 1990 & 408 & 1798 & 2206 & 13.3 & 55.0 & 34.8 \\
\hline West 1996 & 459 & 3377 & 3836 & 14.2 & 99.1 & 57.8 \\
\hline
\end{tabular}

Source: Authors' calculations based on data from the Kannisto-Thatcher Oldest Old Database (Kannisto, 1994). 


\section{Figure 1:}

Life Expectancy at Birth in East and West Germany, 1970-1996

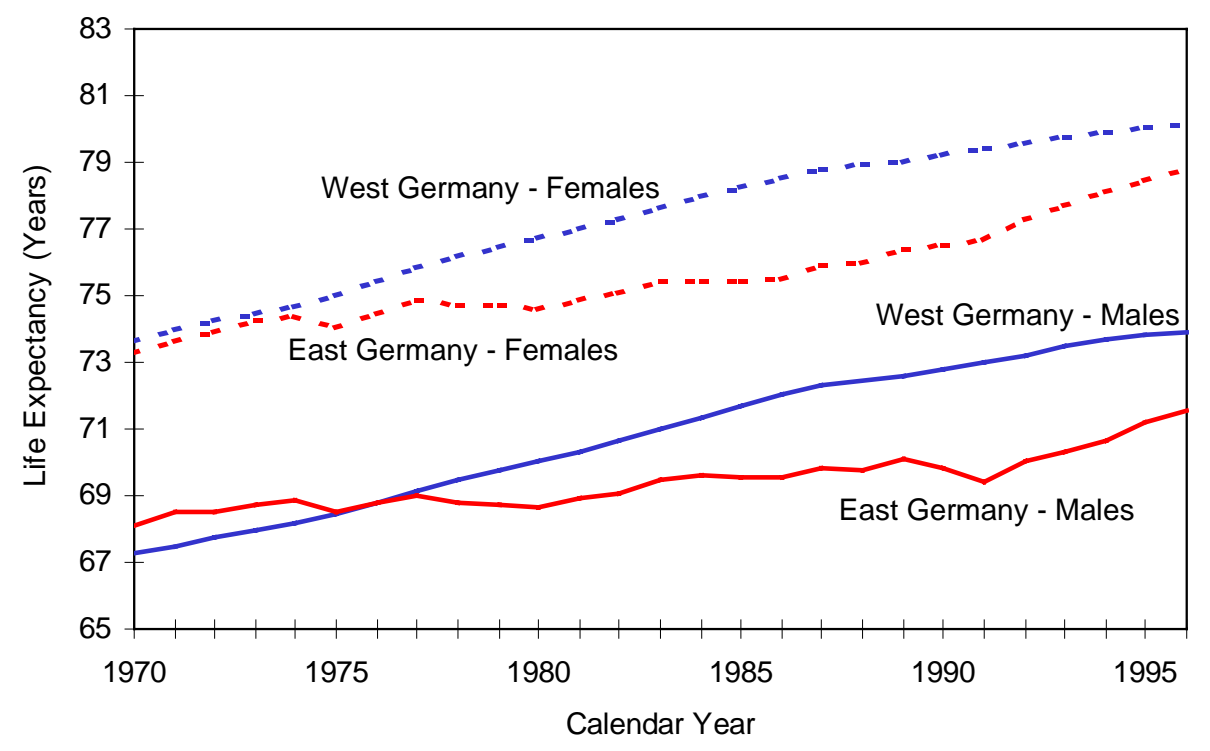

Source: Statistisches Bundesamt, 1980-1998. 
Figure 2a:

Contribution of Different Ages to Changes of Life Expectancy at Birth East Germany - Females

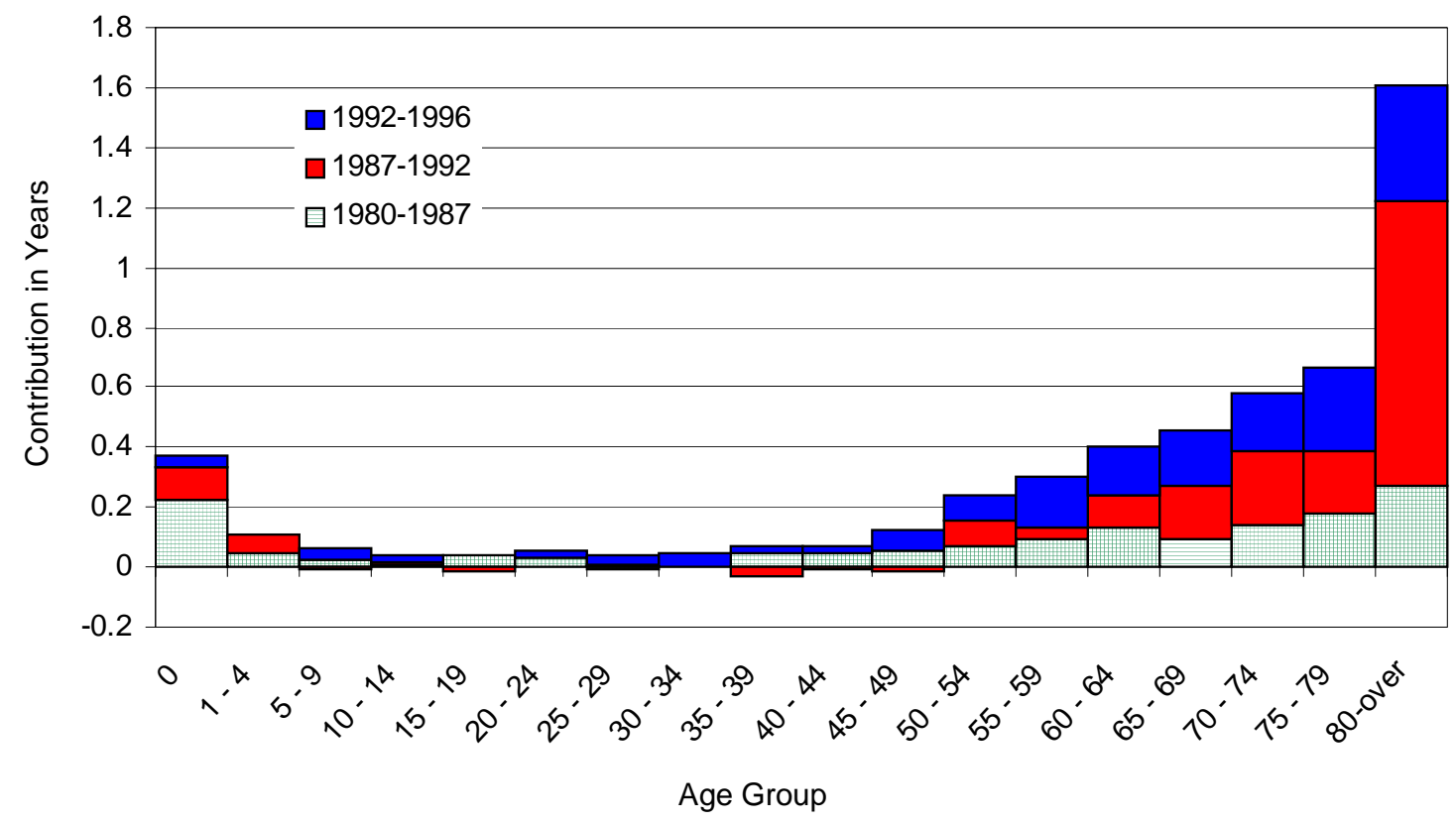

Figure 2b:

Contribution of Different Ages to Changes of Life Expectancy at Birth

West Germany - Females

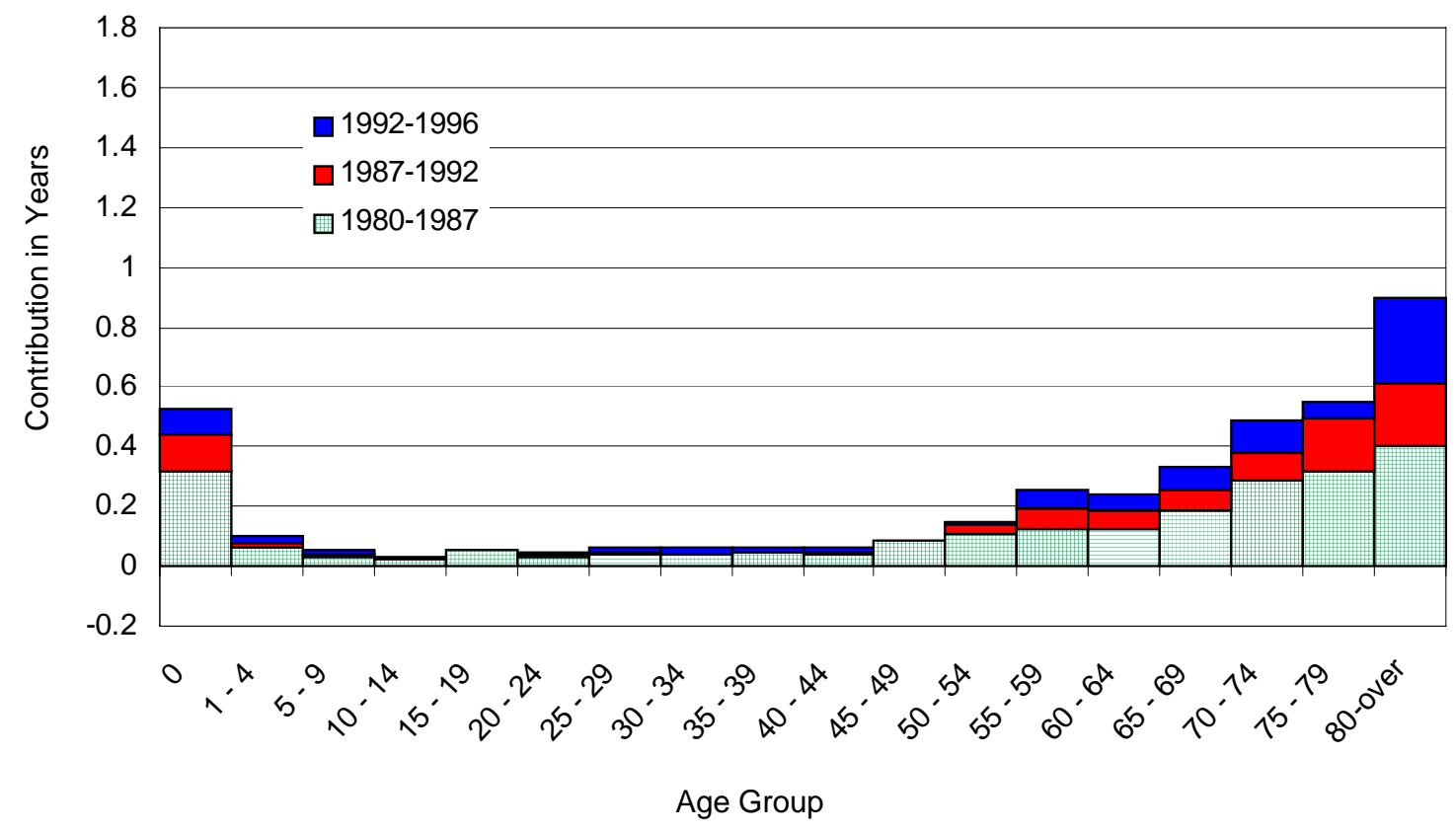

Source: Authors' calculations based on data from Statistisches Bundesamt, 1980-1998. 


\section{Figure 3a:}

Contribution of Different Ages to Changes of Life Expectancy at Birth East Germany - Males

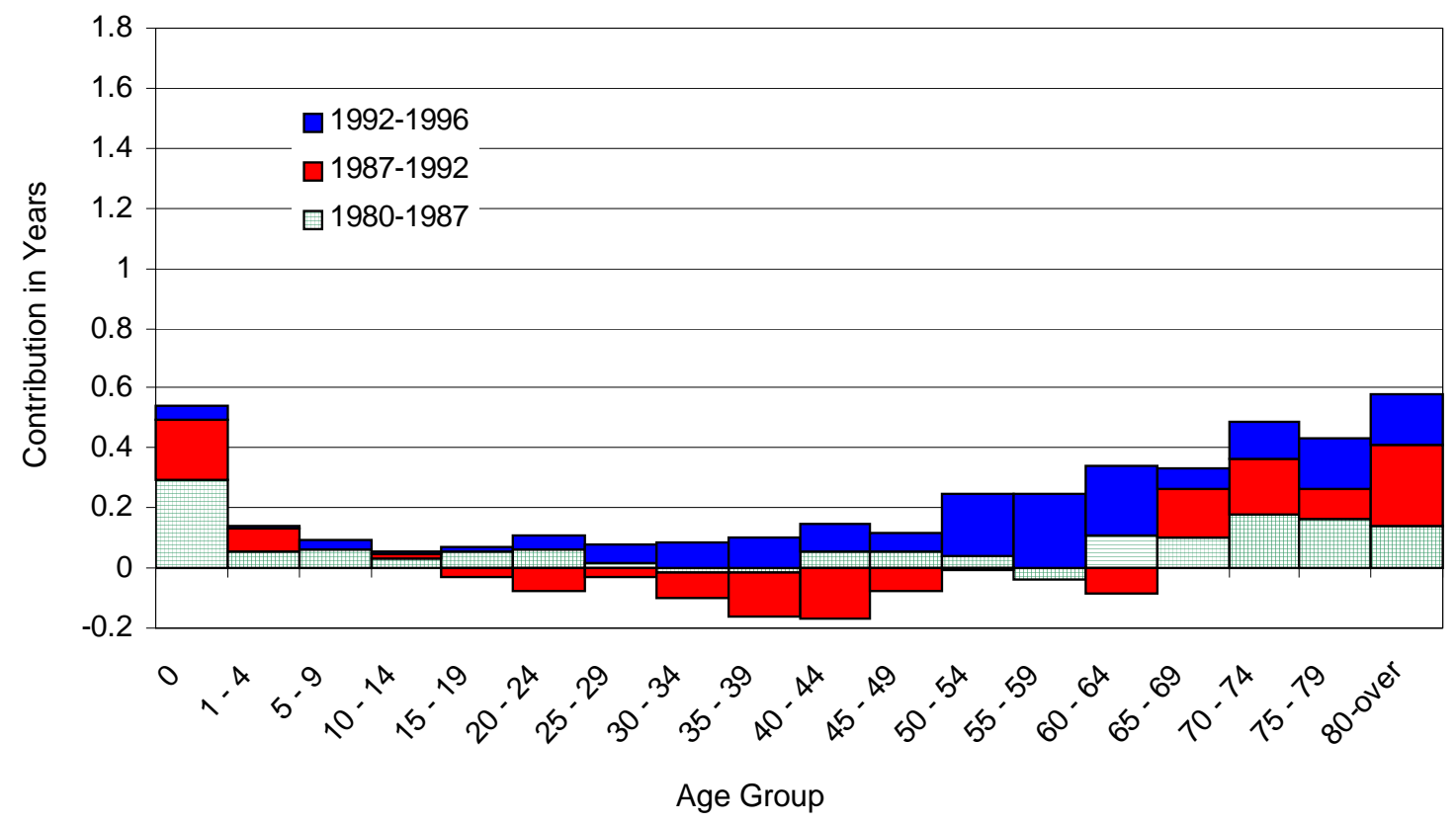

\section{Figure 3b:}

Contribution of Different Ages to Changes of Life Expectancy at Birth West Germany - Males

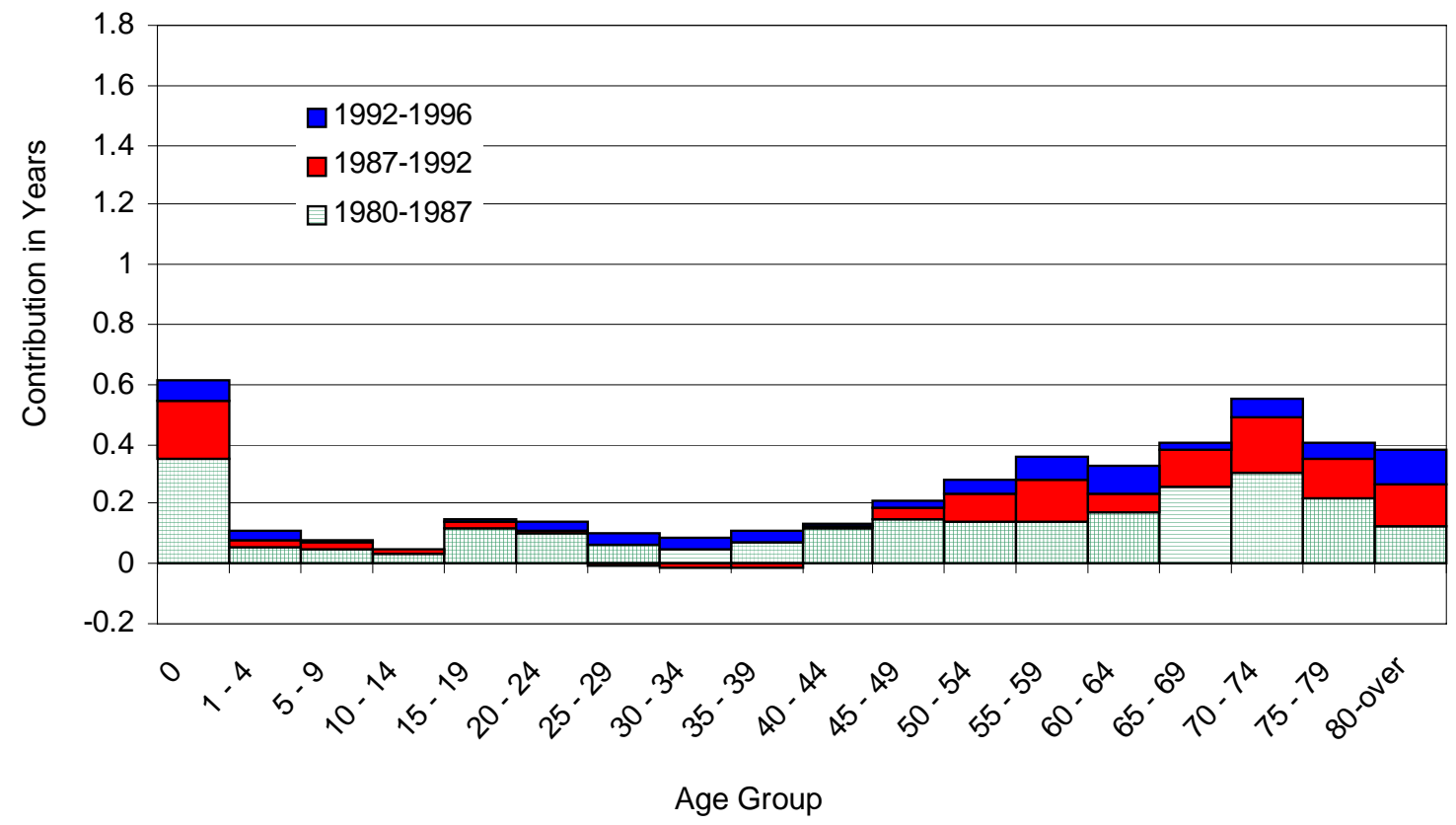

Source: Authors' calculations based on data from Statistisches Bundesamt, 1980-1998. 


\section{Figure 4a:}

Average Annual Rate of Mortality Decline by Age Groups

East Germany - Females

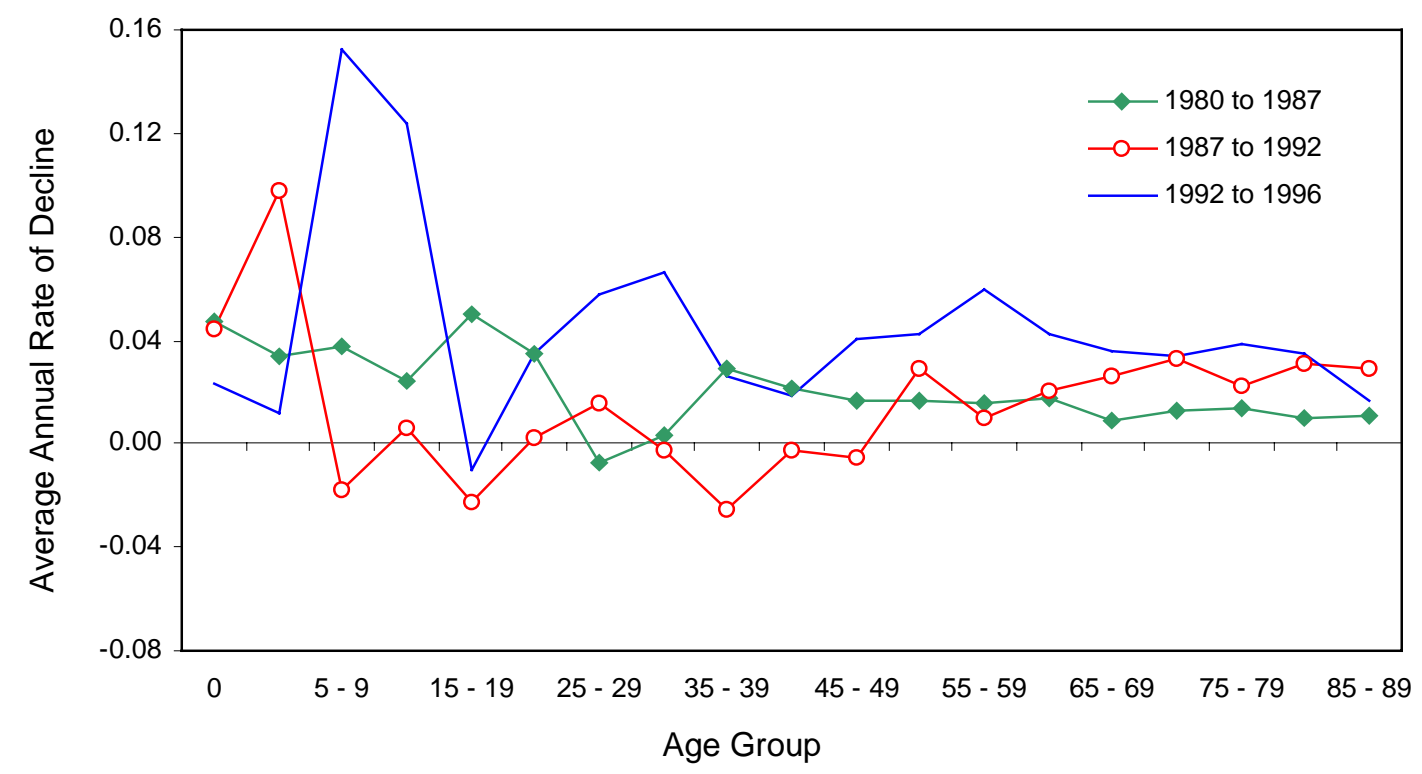

\section{Figure 4b:}

Average Annual Rate of Mortality Decline by Age Groups

West Germany - Females

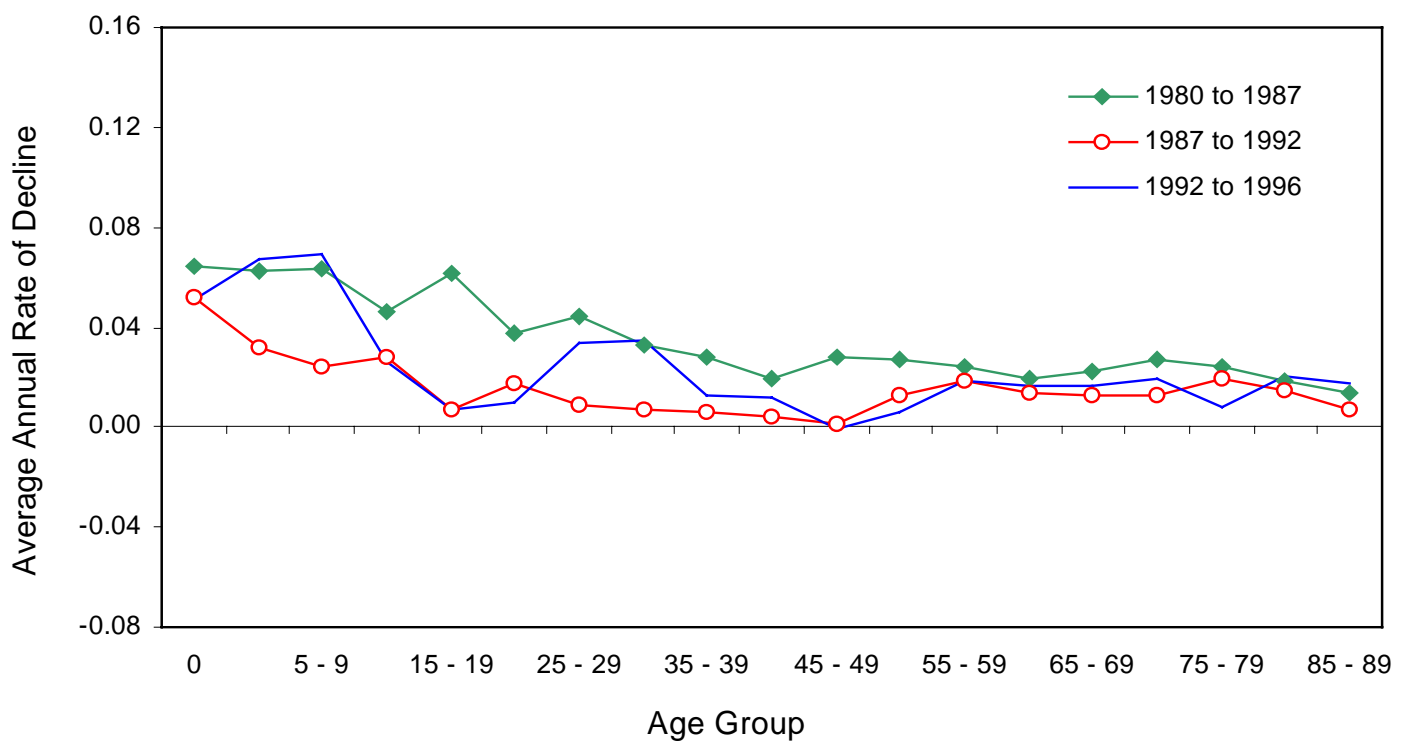

Note: The average annual rate of mortality decline was calculated as $-\ln \left(Q_{2} / Q_{1}\right) /\left(t_{2}-t_{1}\right)$ where $Q_{1}$ and $Q_{2}$ are the age-specific probabilities of dying for the first and last year of a period, and $t_{1}$ and $t_{2}$ are the first and last year of that period.

Source: Authors' calculations based on data from Statistisches Bundesamt, 1980-1998. 


\section{Figure 5a:}

Average Annual Rate of Mortality Decline by Age Groups

East Germany - Males

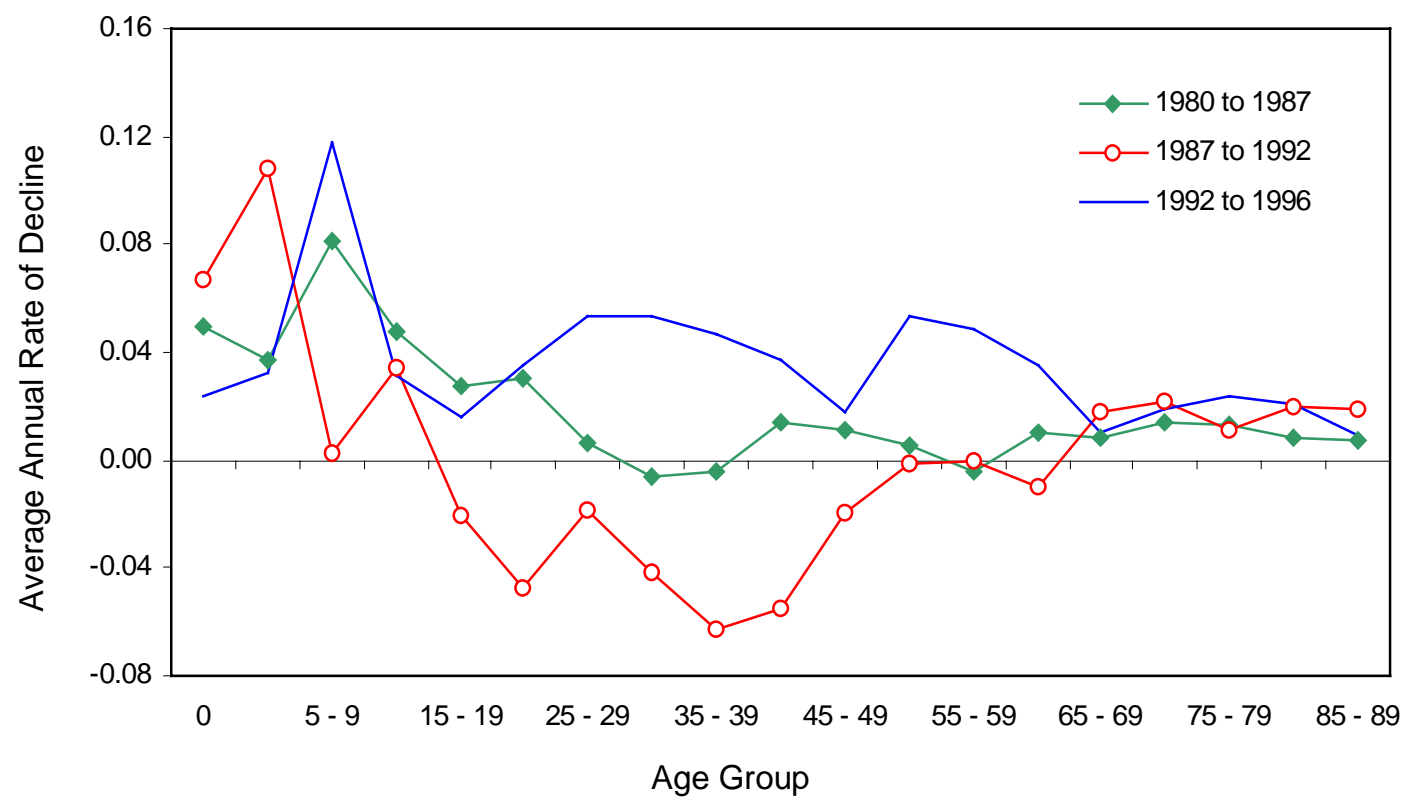

\section{Figure 5b:}

Average Annual Rate of Mortality Decline by Age Groups

West Germany - Males

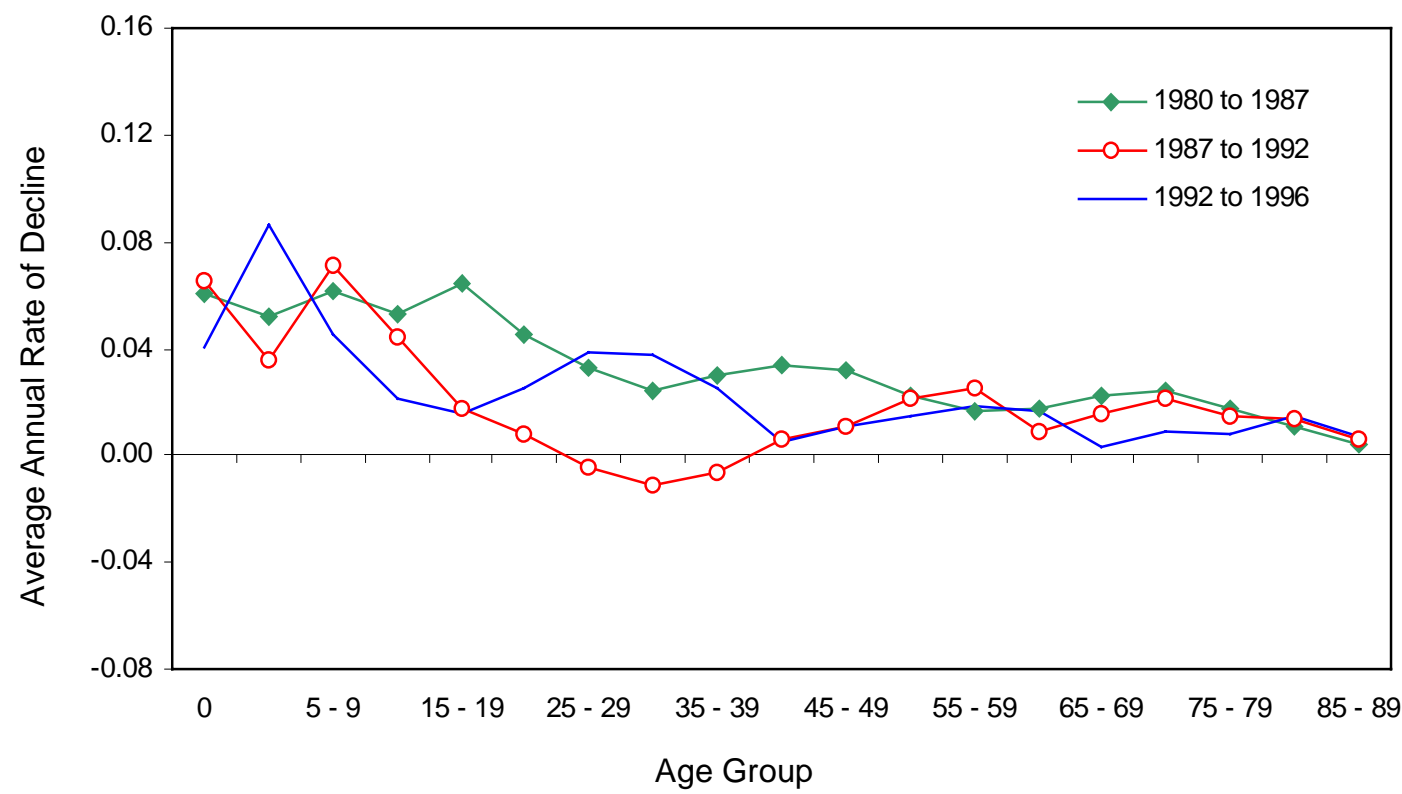

Note: The average annual rate of mortality decline was calculated as $-\ln \left(Q_{2} / Q_{1}\right) /\left(t_{2}-t_{1}\right)$ where $Q_{1}$ and $Q_{2}$ are the age-specific probabilities of dying for the first and last year of a period, and $t_{1}$ and $t_{2}$ are the first and last year of that period.

Source: Authors' calculations based on data from Statistisches Bundesamt, 1980-1998. 


\section{Figure 6:}

Central Death Rates for East and West Germany for Ages 80 to 99, 1955-1996
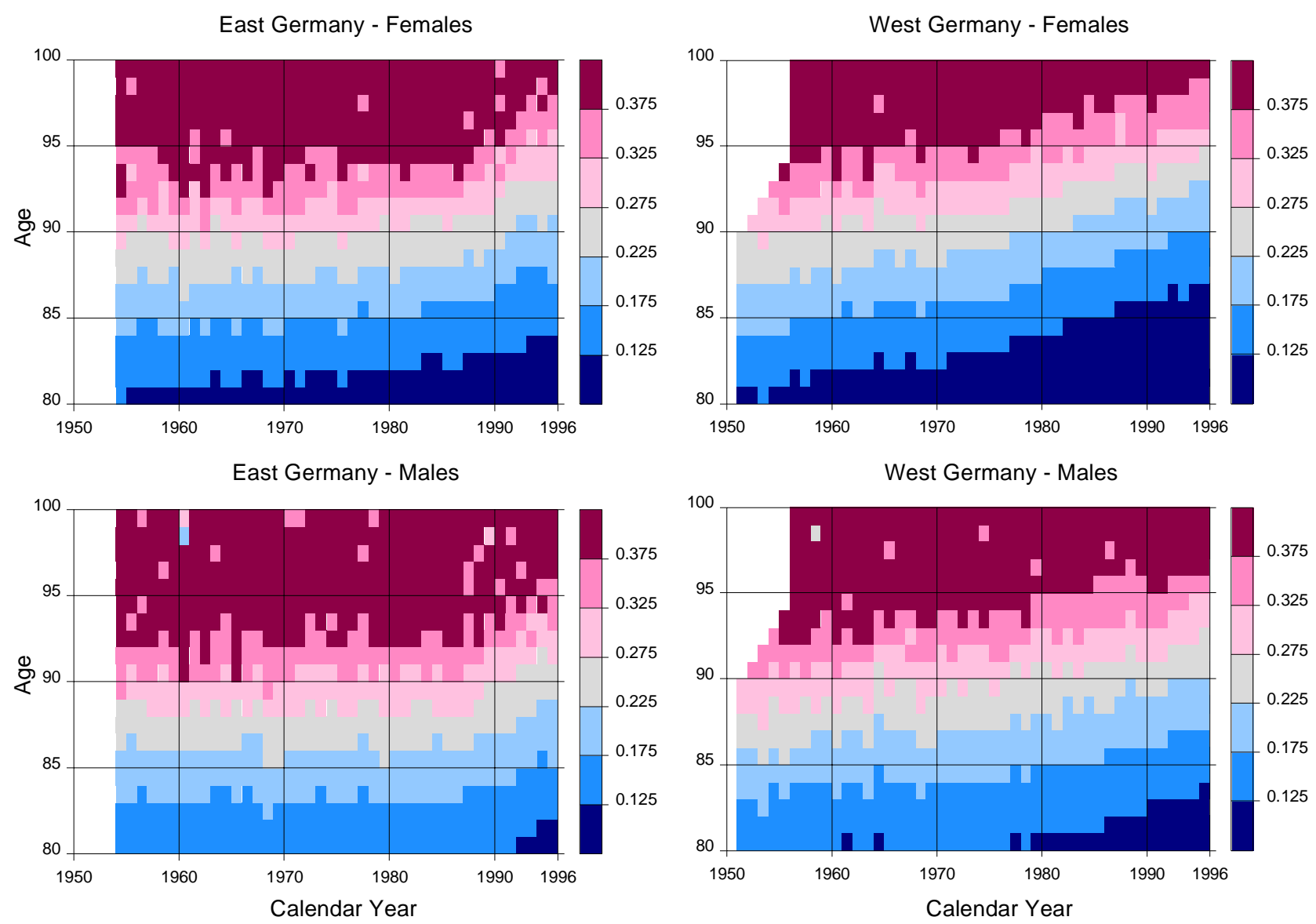

Source: Authors' calculations based on Kannisto-Thatcher Oldest Old Database 


\section{Figure 7:}

Death Rate Ratios of East/West Germany for Ages 80 to 99, 1955-1996
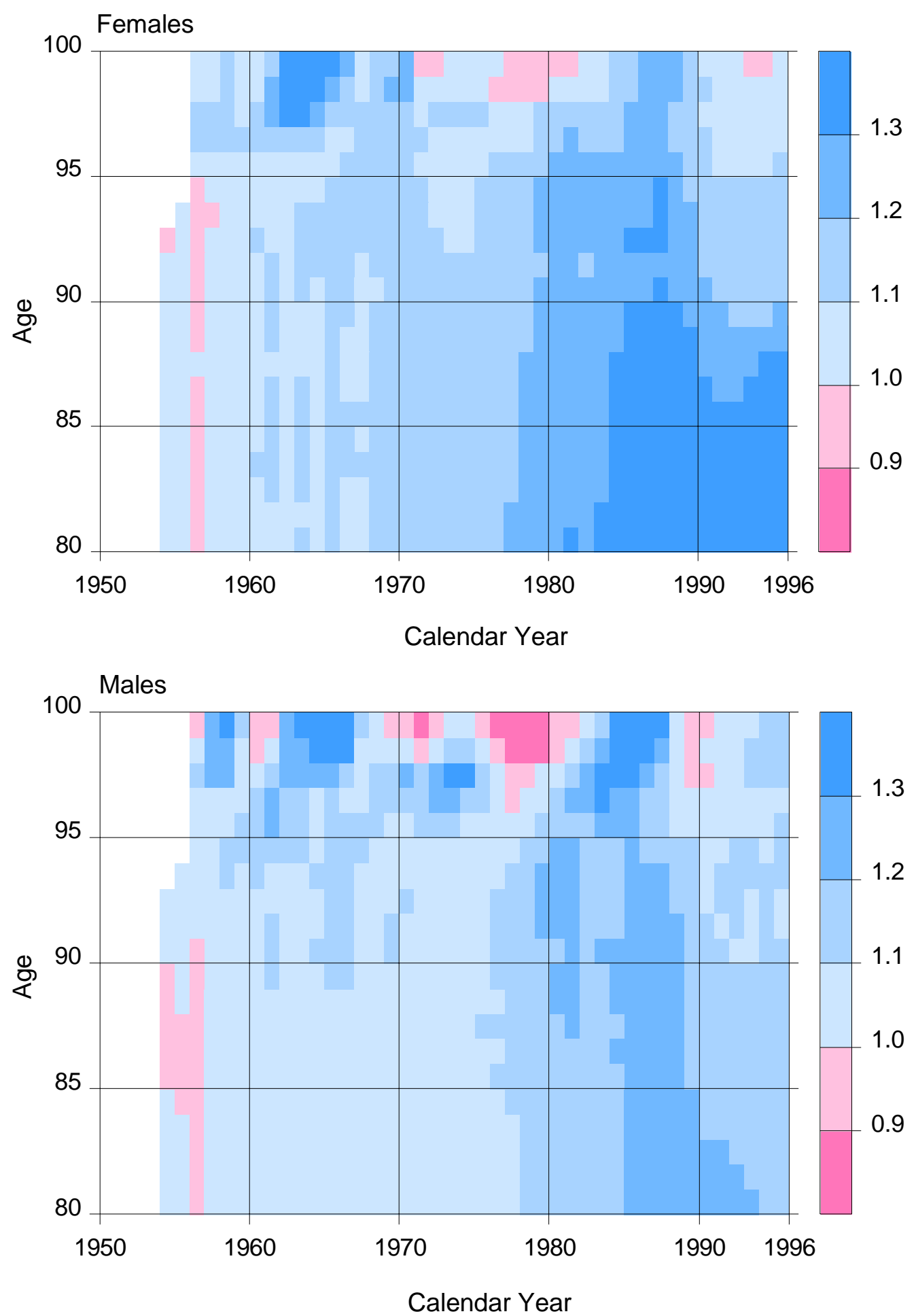

Note: A weighted average smoothing method was applied for these two maps Source: Authors' calculations based on Kannisto-Thatcher Oldest Old Database 